\title{
Aleksandra Spik*
}

\section{GOOD SOLDIERS IN ORGANIZATIONS- HEROES, ACTORS OR VICTIMS-RECENT TRENDS IN RESEARCH ON ORGANIZATIONAL CITIZENSHIP BEHAVIOR}

\begin{abstract}
A b s t r a c t: Research on organizational citizenship behavior often suggest that employees who engage in such behavior are good soldiers of organization who perform discretionary and selfless actions of help and compliance. OCB is frequently recognized as indisputably positive behavior The aim of this article is to take a more nuanced view of organizational citizenship behavior and describe its dark side. First, the concept of organizational citizenship behavior is defined, the main research areas and the history of the construct. Secondly, the issue of differentiating between good soldiers and good actors is introduced followed by the research evidence. Then, the empirically supported negative consequences of OCB for organizations and individuals are enumerated. Finally, the conclusions and implications for practitioners and researchers are discussed.
\end{abstract}

K e y w o r d s: organizational citizenship behavior, impression management, counterproductive work behavior, moral licensing.

J E L C 1 a s s if i c t a o n: J24; L26.

\section{INTRODUCTION}

Contemporary organizations have sought new ways to achieve stable competitive advantage. Extra-role behaviors are believed to be one of the most promising areas of a potential competitive advantage since these kind of behaviors serve organizational good and are not easily copied by competitors. Extra- role behavior have been identified under variety of names from which one of the most recognizable are organizational citizenship behavior (OCB). Organizational citizenship behaviors refer to these activities of employees that exceed the minimum requirements of the job and are not easily enforceable. Moreover, they support the broader social and psychological environment of the organization and they in the aggregate promote the functioning of organi-

\footnotetext{
* Adres do korespondencji: Aleksandra Spik, Uniwersytet Warszawski, Wydział Zarządzania, Katedra Teorii Organizacji, ul. Szturmowa 1/3, 02-678 Warszawa, e-mail: aspik@wz.uw.edu.pl
} 
zation and they in the aggregate promote the functioning of organizations [Organ, 1997]. These actions are typically considered to be less likely to be rewarded by organization and are more discretionary then in-role task performance. [Organ, Podsakoff, MacKenzie, 2006]. The researchers and practitioners have become interested in OCB also because it is considered vital to an organization's performance and long-term viability [Bolino, 1999, Organ, Podsakoff, MacKenzie, 2006]. Given the importance of citizenship behavior, a great deal of research has sought to identify its antecedents [Organ 1997] and outcomes that are desired by organizations, such as organizational effectiveness [Bergeron, 2007].

The aim of this paper is to take a more nuanced view of OCB's while highlighting the recent stems of research. Several researchers have noted recently that OCB have also surprising negative aspects. A number of studies indicated that there might be a dark side to performing OCB [Bergeron, 2007; Bolino, Klotz, Turnley and Harvey, 2012; Klotz, Bolino, 2013]. Citizenship behavior proved to be related with personal and professional costs for individuals and can also lead to negative outcomes in terms of organizational functioning (counterproductive work behavior, moral licensing). Moreover, questions have been raised about the motivational bases for OCB, since motives may influence the effect such behaviors have on the individual image as well as organizational effectiveness [Bolino at al., 2012].Thus, the purpose of this article is to contribute to a better understanding of citizenship behavior and offer a review of the most intriguing outcomes and correlates of the construct.

The reminder of the article is structured as follows. First we present the theoretical construct of OCB. Then the impression management tactics (IM) are introduced and empirical evidence for the complex relationships between IM and OCB are presented. Afterwards, the negative outcomes of OCB in terms of the organization and the individual are enumerated. Finally, we discussed the complex view of OCB and implications for further research.

\section{ORGANIZATIONAL CITIZENSHIP BEHAVIOR- THE CONSTRUCT EFINITION AND HISTORY}

Thomas Bateman and Dennis Organ first coined the term in 1983 [Bolino, 1999]. Since then, organizational citizenship behavior has been the focus of a great deal of research. More than 2,100 articles on OCB have been published, with almost half appearing over 2010 [Klotz, Bolino, Song, Spoelma, 2018]. Most research of OCB focuses on antecedents of such behavior. Across the body of work three steams of research can be identified. The first stem of research on antecedents of $\mathrm{OCB}$ follows a social exchange perspective including job attitudes and personality traits [i.e. Organ and Ryan, 1995, Organ, Podsakoff, Mac Kenzie, 2006]. The second stem of research refers to functional approach to behavior and 
seek for the purpose behind OCB [i.e. Bolino, Rioux, Penner, 2001; Guzman, Espejo, 2015[. The third part of research concentrate on exploring relationships between OCB and organizational or individual outcomes, such as: promotions, family-work conflict, job stress, work overload [i.e. Bolino, Klotz, Turnley and Harvey, 2013, Organ, Podsakoff, MacKenzie, 2006, Bergeron, 2007].

The idea of extra role behaviors and its impact on the effectiveness of organizations can be traced to the 1966, when Katz and Kahn first published The Social Psychology of Organizations, one of the best known and the most comprehensive behavioral analysis. The authors indicated that there are three forms of people's contributions that are necessary for the effective functioning of every organization. One of the necessary contributions was defined as "innovative and spontaneous behavior: performance beyond role requirement for accomplishments of organizational functions " [1978: 337]". This category comprises cooperative activities with fellow members, protection of the organizational system, self-training for additional contribution and creating good image of the organization in the external environment [Organ, Podsakoff, MacKenzie, 2006]. The assertion of Katz and Khan was that "an organization that depends solely upon its blueprints of prescribed behaviors is a fragile social system" [1978:132]. Other researcher have built on that thesis developing theory and research on OCB. Organ and colleagues [2006] conducted a thorough and comprehensive study on the existing body of research on the dimensions and categories of OCB that were empirically supported. They have pointed out several constructs overlaps and inconsistencies in definitions. In order to offer a precise and complete framework for future research they have introduced a typology of OCB that encompasses all the behaviors meeting the criteria for OCB [Organ at al., 2006]:

1. Organizational compliance. Examples of organizational compliance include an employee adhering to an organization's rules and regulations even when breaking the regulations would not be noticed by anyone; not using all of vacation or sick days if is not absolutely necessary. Organizational compliance refers to behavior that is not directed at another individual.

2. Sportsmanship. Sportsmanship is an employee's willingness to deal with tough situations without complaining. Keeping good attitude to work even in difficult situations. For example, not engaging in gossip and not complaining about office size would be considered good sportsmanship.

3. Civic Virtue. Participation in organization political life and supporting the administrative function of the organization such as attending meetings which are not required by the firm and keeping up with the changes in the organization. An example of civic virtue would be attending company events, such as meetings or picnics. It also includes contributing opinions on important organizational issues. 
4. Helping behavior. Helping behavior includes altruism, peacekeeping, and cheerleading. Some examples of helping behavior include volunteering to help others in resolving work-related problems. Helping is demonstrated through communication and consideration for others.

5. Individual initiative. Individual initiative includes voluntary taking on new responsibilities and tasks that serve organizational good, encouraging other coworkers to do the same, seeking better ways of performing one's job.

6. Organizational loyalty. Showing a good image of the organization to the external individuals. Protecting the organization when it is criticized by the people outside organization. Promoting a good image of the organization.

7. Self development. Self development is performed by discretionary activities aimed to develop one's knowledge and skills in order to work better on the current position, such as following trends and developments in the professional field to be up to date with the cutting edge solutions.

\section{GOOD SOLDIERS OR GOOD ACTORS-IMPRESSION MANAGEMENT AND ITS RELATIONSHIP WITH ORGANIZATIONAL CITIZENSHIP BEHAVIOR}

Whenever the employee's behavior in the workplace is motivated by the desire to influence the image others have of the actor, it may be called impression management tactic [Jaiswal, Bhal, 2014]. Impression management is defined as "behaviors that individuals use in order to create a favorable image of themselves among their colleagues or superiors" [Bolino and Turnley, 2003, p. 63]. Impression management behaviors are viewed as mechanisms to acquire valuable resources within the workplace. Individuals through the usage of IM tactics aim to maximize desirable outcomes and minimize undesirable outcomes in the workplace. The general goal of using impression management is to shape the images held in the minds of supervisors and coworkers. It is a long-term strategy to obtain salary increases, promotions and career advancement. Researchers have identified several tactics that people use to boost their image at work. There are a number of typologies of impression management tactics in the literature. One that is predominantly used in research is known as a Five-factor model of IM and includes 5 types of impression management tactics that are listed below [Bourdage, Wiltshire and Lee, 2015]:

1. Ingratiation. This tactic includes behaviors such as complimenting one's colleagues, conformity or doing favors for them to be seen as likable and friendly.

2. Autopromotion. Exaggerating one's own accomplishments; self-promo- 
tion to be seen as competent by the target. These behavior include taking credit for other people's work.

3. Exemplification. Going above and beyond what is expected to be seen as dedicated by the target of IM. These behaviors include coming in early or staying late to appear hardworking and dedicated, volunteering for tough assignments. Exemplification also includes behaviors such as trying to appear busy even when things are slower.

4. Intimidation. This group of behaviors aim at signaling power or potential to punish to be seen as dangerous by the target of IM. Intimidation is used towards coworkers or subordinates.

5. Supplication. Behaviors that lead to advertising one's weaknesses to be seen as needy by the target of IM tactic, the aim is to evoke feelings of social responsibility in others. The purpose of such behaviors is to be frequently helped by others, so as one can work less than it is required for the job.

The particular popularity of the Five factor model is caused by two aspects. First of all, the model has been operationalized by Bolino and Turnley [1999] and reliable scales to measure all five types of IM have been developed (known as IM-5). Additionally, the model encompasses a relatively wide array of behaviors grouped in separate categories.

Although IM is a separate construct from OCB, it has become an important issue in the discussion on OCB since the reflection on the motives of OCB was introduced into the research. Many of the impression management tactics listed above can appear very similar to citizenship behavior. For example helping to one's co-worker can be a purely altruistic act or a temporary strategy to impress the supervisor. Therefore, it has been indicated that there is a need to explain how to differentiate altruistic, selfless deeds from behaviors aimed at creating only an impression of a good citizen [Bolino, 1999]. In addition, several researchers have noted that engaging in citizenship behavior might be quite self-serving and impression enhancing [Bolino, 1999]. Other researchers have started to identify the reasons that motivate employees to engage in $\mathrm{OCB}$, what has broaden the definition of OCB beyond the borders set previously by Dennis Organ [Rioux, Penner, 2001].

Rioux and Penner [2001] identified three key motives that are behind OCB: prosocial values (PV) motives are the employee's desire to help and connect with others; organizational concern (OC) motives describe an employee's desire to help and be fully involved with the organization; and impression management (IM) motives describe an employee's desire to be seen positively and to avoid being seen negatively. Prosocial values and organizational concern represent traditional good soldier motives and impression management motive represent good actors rather than good soldiers of organization. Therefore, researchers 
have introduced the concept of pseudo-OCB [Snell, Wong, 2007]. Pseudo-OCB is observed when an employee is just pretending to perform the behavioral content of citizenship behavior, without actually engaging in OCB. For example, an employee may be present in the office during the weekend claiming to complete business assignment but in fact may use office equipment for personal affairs. A pseudo-OCB would also be the case if a colleague sabotages another colleague's work while pretending to provide him/her with spontaneous help and guidance. The researchers argue that pseudo-OCB is a dangerous phenomena in organizations due to its three socially undesirable attributes: opportunistic motives, attempts to mislead and counterproductive behavior covered-up by the impression management behavior [Snell, Wong, 2007].

\section{GOOD CITIZENS OR VICTIMS-NEGATIVE OUTCOMES OF ORGANIATIONAL CITIZENSHIP BEHAVIOR}

Recent theoretical and empirical work suggest that is some cases performing citizenship behaviors may be merged with negative consequences for the actors or/and for the organization. In the table 1 costs of OCBs are summarized regarding individuals and organizations, the definition of every phenomenon is also presented.

Table 1Title: Organizational and individual costs of organizational citizenship

\begin{tabular}{|c|c|c|}
\hline Cost of citizenship behavior & Authors & Description \\
\hline Citizenship pressure & $\begin{array}{c}\text { Bolino at al. } \\
(2010)\end{array}$ & $\begin{array}{c}\text { "Specific job demand in which an employee feels } \\
\text { pressured to perform OCB's" (p.836) }\end{array}$ \\
\hline Work overload & $\begin{array}{c}\text { Bolino and } \\
\text { Turnley, (2005) }\end{array}$ & $\begin{array}{c}\text { OCB Individual initiative was positively associated } \\
\text { with work overload, job stress and work-family } \\
\text { conflict, especially among women }\end{array}$ \\
\hline Negative task performance & $\begin{array}{c}\text { Bergeron, } \\
2007\end{array}$ & $\begin{array}{c}\text { Employees who engage in OCB use resources for } \\
\text { these behavior, such as time and energy. It tends to } \\
\text { negatively affect their task performance }\end{array}$ \\
\hline Job creep & $\begin{array}{c}\text { Spitzmuller, } \\
\text { Van Dyne and } \\
\text { Elis (2013) }\end{array}$ & $\begin{array}{c}\text { "Slow and subtle expansion of duties" (p.181) Per- } \\
\text { forming OCB leads to broadening the expectations } \\
\text { of the employer. }\end{array}$ \\
\hline $\begin{array}{c}\text { Compulsory citizenship be- } \\
\text { havior }\end{array}$ & $\begin{array}{c}\text { Vigoda-Gadot } \\
(2007)\end{array}$ & $\begin{array}{c}\text { Managers requires from employees work that go } \\
\text { beyond and above the job description }\end{array}$ \\
\hline $\begin{array}{c}\text { Lack of job satisfaction } \\
\text { Munyon at al. } \\
(2010)\end{array}$ & $\begin{array}{c}\text { High levels of citizenship are positively related with } \\
\text { low levels of job satisfaction for employees with low } \\
\text { levels of optimism }\end{array}$ \\
\hline $\begin{array}{c}\text { Counterproductive work behav- } \\
\text { ior (moral licencing) }\end{array}$ & $\begin{array}{c}\text { Klotz and } \\
\text { Bolino, (2013) }\end{array}$ & $\begin{array}{c}\text { Moral licensing theory suggests that certain OCBs } \\
\text { may license subsequent counterproductive acts. }\end{array}$ \\
\hline
\end{tabular}

Source: own elaboration based on: Bergeron, 2007;Vigoda-Gadot, 2007; Bolino and Turnley, 2005; Bolino at al., 2010; Klotz and Bolino, 2013; Sptzmuller at al., 2013; Munyon at al., 2010. 
First of all, the discretionary characteristic of OCB has been put into question [Vigoda-Gadot, 2007, Spitzmuller, van Dyne, 2013]. Researchers argue that when OCB's are performed regularly over time, activities that were once considered beyond the scope of job requirements slowly are becoming part of employee's expected duties, the phenomenon was labeled job creep [Spitzmuller, van Dyne, 2013]. Aditionally, it is suggested that job creep makes employees feel that it infringes on their personal freedom.

Secondly, it has been noticed that some organizations eliminate the discretionary factor of OCB even though an employee has not started yet to perform OCB on regular basis [compulsory organizational citizenship, Vigoda-Gadot, 2007]. This organizations require that employees will go above they normal job duties. Research evidence shows that compulsory citizenship behavior are positively related to job stress, intension to quit and burnout and negatively correlated with job satisfaction and innovation [Vigoda-Gadot, 2007].

Mark Bolino with team [2010] has investigated a similar phenomenon, labelled citizenship pressure. It has been observed that citizenship pressure predicts work-family conflict, work-leisure conflict, job stress and intension to quit [Bolino at al., 2010].

Organizational citizenship behavior are claimed to be positively related to job satisfaction [Organ,

1997]. This relationship is deeply rooted in the theory of OCB, since OCB is believed to be one of the main consequences of high levels of job satisfaction. This hypothesis has been supported by research evidence, also in the groups of Polish employees [Spik, 2016]. Whilist Munyon, Hochwarter, Perrewe and Ferris [2010] obtained an opposite result when they selected a specific sample of employees. The criterion of selection was the level of optimism. The researchers demonstrated that OCB was positively related to job satisfaction among employees who were high in optimism. However, among individuals who were less optimistic the relationship between OCB and job satisfaction was curvilinear. OCB was positively related to job satisfaction up to a point, then more OCBs were associated with decreased levels of job satisfaction.

Another individual cost of prosocial behaviors at work regards task performance. Individuals have not enough work time to devote both to task performance and OCB. Thus, engaging in OCB may result in sacrificing in-role task and, therefore, get fewer promotions and smaller increases in salaries [Bergeron at al., 2013]. Negative effect of OCB on career is especially strong if the organization tends to reward results rather than behavior.

Bergeron and colleagues [2013] have studied the relationship between OCB, task performance and career outcomes in professional services firms operating within an outcome-based reward system. Their findings suggested that the relationship between the examined variables might be more complex than it was 
previously though. Earlier research has demonstrated that OCB is an important factor in performance evaluations perceived by supervisors [metanalysis done by Podsakoff at al., 2009]. However, it seems not to be the case in the outcomebased reward systems, where task performance is weighted much higher than OCB. Moreover, Bergeron at al. [2013] have demonstrated that there is a negative correlation between the time spent on OCB and the time spent on task performance. In other words, there is a trade-off between task performance and OCB. Therefore, employees highly engaged in OCB cannot allocate the same amount of resources (time, energy) in task performance. Furthermore, the results shows that time spent on task performance was positively related with career advancements, salary increases and promotion, whereas time spent on OCB had a negative correlation with all those three variables.

Klotz and Bolino [2013] investigated on negative outcomes of OCB regarding organizational functioning. This paradoxical effect (since OCB by definition serves organizational good) can beexplained by the presence of certain organizational conditions and using moral licensing theory.

One of the possible negative outcome regarding organization is counterproductive work behavior (CWB) performed by employees who were previously identified as those engaging in voluntary and altruistic acts of help, compliance or sportsmanship. Counterproductive work behavior describes activities that impair the organization. This category encompasses tardiness, theft, workplace bullying or sabotage. Not only do these acts harm the organization but also affect negatively the productivity of other employees and create unfavorable work climate. However, Bolino and Klotz [2013] do not claim that every employee highly engaged in OCB is prone to counterproductive work behavior, they argue, though, that under certain conditions this phenomenon may occur. First of all, employees may resent feeling forced to perform OCBs because of incompetent coworkers, organizational constraints, or supervisor demands. Therefore, employees who feel that they have not been fairly rewarded for OCBs that they have undertaken for these reasons will feel angry and be more likely to engage in counterproductive acts. Finally, the mechanism of moral licensing may occur.

Moral licensing theory describes how positive acts may internally license people to engage in negative behaviors but also explains how observers may license such behaviors. Indeed, studies show that people are less willing to condemn wrongdoers who have previously performed good deeds [Klotz and Bolino, 2013]. Moreover, employees try to maintain an internal moral equilibrium, namely, they balance the number of good and bad deeds to match the internal image of self moral evaluation. The general assertion here is that people are not trying to pursue the ideal moral image of themselves, they had rather stay with a stable and balanced moral self [Miller, Effron, 2010]. Studies also show that prior "good" acts can enable people to establish moral credentials that actually 
alter the way their subsequent misdeeds are interpret by themselves and by others [Miller, Effron, 2010]. For example, an employee who has gained a moral license from engaging in OCBs may not engage in CWBs until he or she comes across a task at work that particularly dislikes and will feel licensed to leave the task undone. A moral license removes a psychological barrier that keeps people from engaging in counterproductive acts that they might wish to engage in but do not for fear of discrediting themselves.

All the above mentioned phenomena generally apply to certain and specific conditions under which negative outcomes may be found. These are situations when employees are compelled to perform OCB or the intensity of the behavior is higher than the employee is willing to perform. However, the negative consequences of the trade-off between OCB and task performance are more difficult to be avoided. In a similar vein, moral licensing mechanism is not to be easily recognized and eliminate by the organization. These facts lead to the conclusion that particular attention shall be paid to this area of organizational functioning since at the same time it might be the source of a great competitive advantage as well as organizational problems.

\section{CONCLUSION AND IMPLICATIONS FOR FUTURE RESEARCH}

It is a fact that organizational citizenship behavior is vital for organizational functioning. Discretionary and not rewarded acts of help, self-development, initiative and compliance are necessary for vitality of every organization. The words of Katz and Khan [1978], that any organization that depends only on the blueprints of prescribed behaviors will not survive, remain undisputable true. However, over three decades of research have proved that the image of OCBs is not as simple as it was previously thought. The purpose of this paper was to offer a review of theories and research evidence that show a more complex view of citizenship behavior in order to offer a better understanding of the phenomenon. Organizational practitioners and researchers should be aware that OCB might be a double-edge sword. On the one hand, it makes organizations more effective but on the other may result in negative consequences for employees. Moreover, behaviors identified as OCB may also impair the organization. The presented research referring to moral licensing theory and impression management could be a warning sign for practitioners signaling that organizations should be cautious in how they promote behaviors of OCB. Further research should focus more deeply on the complex pattern of motives behind OCB and seek to identify the conditions under which citizenship behavior is more harmful then beneficial. 


\section{REFERENCES}

Bergeron, D.M., Shipp, A.J., Rosen, B., Furst-Holloway, S. (2013), Organizational citizenship behavior and career outcomes: The cost of being a good citizen, "Journal of Management" 39/4, 958-984

Bolino, M. (1999), Citizenship and impression management: good soldiers or good actors? "Academy of Management Review", 24/1, 82-98.

Bolino, M., Klotz, A.C., Turnley, W.H., Harvey, J. (2013), Exploring the dark side of organizational citizenship behavior, "Journal of Organizational Behavior", 34, 542-559

Bolino, M., Turnley, W.H., (2005), The personal costs of citizenship behavior: The relationship between individual initiative and work overload, job stress and work-family conflict, ”Journal of Applied Psychology", 90, 740-748

Bolino, M. C., Turnley, W. H. (2003), Going the extra mile: cultivating and managing employee citizenship behavior, "Academy of Management Executive", 17, 60-71.

Bolino, M., Turnley, W.H., Gilstap, J.B., Suao, M.M. (2010). Citizenship under pressure: What is a "good soldier" to do? "Journal of Organizational Behavior", 31, 835-855

Bourdage, J.S, Wiltshhire, J.W., Lee, K. (2015), Personality and workplace impression management: Correlates and implications, "Journal of Applied Psychology", 100/2, 537-546

Guzman, F.A., Espejo, A. (2015), Dispositional and situational differences in motives to engage in citizenship behavior, "Journal of Business Research", 68, 206-215

Jaiswal, O., Bhal, K.T. (2014), Behavioral Flexibility: The use of upward impression management tactics by subordinates for good performance rating from leader and impact of organizational and leader's Machiavellism, "Global Journal of Flexibility Systems Management", 15/4, 313-326

Katz, R.L., Khan, D. (1978), Społeczna psychologia organizacji. Warszawa: Wydawnictwo Naukowe PWN

Klotz, A.C., Bolino, M.C. (2013), Citizenship and counterproductive work behavior: A moral licensing view, "Academy of Management Review" 38/2, 292-306.

Klotz, A.C., Bolino, M.C. (2013), Citizenship and counterproductive work behavior: a moral licensing view. "Academy of Management Review" 38/ 2, 292-306

Klotz, A.C., Bolino, M.C., Song, H., Stornelli, J. (2018), Examining the nature, causes, consequences of profiles of organizational citizenship behavior, "Journal of Organizational Behavior", 39, 629-647

Miller, D. T., \& Effron, D. A. 2010. Psychological license: When it is needed and how it functions, "Advances in Experimental Social Psychology" 43: 115-155

Organ, D.W. (1997), Organizational citizenship behavior; It's construct clean-up time, "Human performance", 10, 85-97

Organ, D.W., Ryan, K. (1995), A meta-analytic review of attitudinal and dispositional predictors of organizational citizenship behavior, "Personnel Psychology", 48, 775-802

Organ, D.W., Podsakoff, P. M., Mac Kenzie, S.B.(2006), Organizational citizenship behavior: Its nature, antecedents and consequences. California; Sage Publications.

Riki T.; Bolino, M.C., Cheng-Chen L. (2015), Too many motives? The interactive effects of multiple motives on organizational citizenship behavior, "Journal of Applied Psychology" 100/4, $1239-1248$

Rious, S.M. and Penner, L.A. (2001), The causes of organizational citizenship behavior: A motivational analysis, "Journal of Applied Psychology", 86/6, 1306-1314

Scott, C., Dool, R.; Mancini, D. (2018) The effect of paid time off for volunteerism on organizational citizenship behavior: Is It influenced by national culture, "International Journal of Business \& Public Administration" 15 /1, 52-70 
Snell, R.S., Wong, Y.L., (2007), Differentiating good soldiers from good actors, "Journal of Management Studies", 44/6, 884-909

Spik, A. (2016), Enthusiasts or trapped Enthusiasts or Trapped? Relations between organizational commitment profiles, organizational citizenship behavior and life satisfaction, "Journal of Entrepreneurship, Management and Innovation", 1-36

Spitzmuller, M.; Van Dyne, Linn (2013), Proactive and reactive helping: Contrasting the positive consequences of different forms of helping ,Journal of Organizational Behavior”34/4, 560 580

Vigoda-Gadot, E. (2007), Redrawing the boundaries of OCB? An empirical examination of compulsory extra-role behavior in the workplace. "Journal of Business \& Psychology"21/3, $377-405$

\section{DOBRZY ŻOŁNIERZE ORGANIZACJI - BOHATEROWIE, AKTORZY CZY OFIARY-WSPÓŁCZESNE TRENDY W BADANIACH NAD ORGANIZACYJNYMI ZACHOWANIAMI OBYWATELSKIMI}

Zarys treści: Zachowania obywatelskie w organizacji (organizational citizenship behavior, OCB) są najczęściej przedstawiane w literaturze jako zjawisko jednoznacznie pozytywne. Dobrowolne działania ze strony pracowników, które wykraczają poza zakres obowiązków, nie są wynagradzane i służą dobru organizacji są często postrzegane jako najbardziej pożądane przez organizację. Celem artykułu jest pokazanie innego oblicza zachowań obywatelskich, ich negatywnych konsekwencji dla organizacji i pracownika. W artykule przedstawiony jest przegląd najnowszej literatury i badań dotyczących związków OCB i zarządzania własnym wizerunkiem oraz szereg przesłanek teoretycznych i empirycznych wskazujących na związki OCB z moralnym samopobłażaniem oraz z zachowaniami przeciwproduktywnymi.

Słowa kluczowe: zachowania obywatelskie w organizacji, zarządzanie własnym wizerunkiem, moralne samopobłażanie, zachowania przeciwproduktywne 
